\title{
A new durophagous scincomorphan lizard genus from the Late Cretaceous Iharkút locality (Hungary, Bakony Mts)
}

László Makádi ${ }^{\mathrm{a}, \mathrm{b}, \mathrm{c}, *}$ and Randall L. Nydam ${ }^{\mathrm{d}}$

${ }^{a}$ Geological and Geophysical Collections, Geological and Geophysical Institute of Hungary, Budapest, Hungary

${ }^{\mathrm{b}}$ Department of Paleontology and Geology, Hungarian Natural History Museum, Budapest, Hungary

${ }^{\mathrm{c}}$ Department of Paleontology, Eötvös University, Budapest, Hungary

${ }^{\mathrm{d}}$ Department of Anatomy, Midwestern University, Glendale, Arizona, USA

*Corresponding author, email: iharkutia@gmail.com, phone: +36-1-251-0999/373

\begin{abstract}
The Upper Cretaceous (Santonian) Iharkút terrestrial vertebrate locality in Hungary has already yielded scincomorphan taxa such as the polyglyphanodontines Bicuspidon and Distortodon, and the chamopsiid Pelsochamops. Besides these, more lacertilian material is available, including a single right mandible, different from both the above mentioned genera from Iharkút, and from other previously known taxa. This specimen is described here as Chromatogenys tiliquoides gen. nov. sp. nov. The open Meckelian canal, the wide subdental shelf with deep sulcus dentalis, and the pleurodont teeth support referral of the specimen to Scincomorpha. Within that, Chromatogenys differs from groups known from Iharkút, such as polyglyphanodontines and chamopsiids, and is also distinct from other contemporary scincomorphs from Europe, North America and Asia. It exhibits a combination of mixed characters, some of which are shared by scincids, cordylids and contogeniids. Chromatogenys might be a representative of a new family within Scincomorpha but currently should be
\end{abstract}


considered of uncertain familiar relationships (familia incertae sedis) until more material is found. Chromatogenys had a durophagous dentition similar to extant skinks such as Tiliqua, and most probably had similar diet composed of molluscs, eggs, insects, small vertebrates and fruits.

Keywords Squamata; Scincomorpha; durophagous; Iharkút; Csehbánya Formation; Late Cretaceous

Kurzfassung Die terrestrischen Wirbeltier Fundstelle aus der Oberkreide (Santon) in Iharkút, Ungarn hat bereits Skinkartige Taxa wie die Polyglyphanodontinen Bicuspidon und Distortodon und die Chamopsiid Pelsochamops geliefert. Daneben sind weitere Überreste von Eidechsen gefunden, einschließlich eines einzigen rechten Unterkiefers, der sich von denen oben genannten Gattungen aus Iharkút unterscheidet. Dieses Exemplar Chromatogenys tiliquoides gen. nov. sp. nov wird hier wie folgt beschrieben: der offene Meckelische Kanal, der breite subdentale Schelf mit tiefem Sulcus dentalis und die pleurodonten Zähne unterstützen die Bestimmung des Vertreters zu den Skinkartigen. Innerhalb der Scincomorpha Chromatogenys unterscheidet er sich von schon bekannten Gruppen aus Iharkút wie Polyglyphanodontines und Chamopsiids und ist auch unterschiedlich von anderen zeitgleichen Scincomorpha aus Europa, Nordamerika und Asien. Es beinhaltet eine Kombination aus Merkmalen, von denen einige mit den Scinciden, Cordyliden und Contogeniiden geteilt werden. Chromatogenys könnte ein Vertreter einer noch unbekannter Familie von Scincomorpha sein. Aber derzeit ist die phylogenetische Stellung aufgrund von fehlendem Material noch unsicher (familia incertae sedis). Chromatogenys hatte eine durophage Bezahnung ähnlich wie rezente Skinke z. B. Tiliqua, und wahrscheinlich hatte er 
auch eine vergleichbare Ernährung in Form von Mollusken, Eiern, Insekten, kleinen Wirbeltieren und Früchten.

Schlüsselwörter Squamata; Skinkartige; durophager; Iharkút; Csehbánya Formation; Oberkreide

\section{Introduction}

The Late Cretaceous (Santonian) terrestrial vertebrate locality at Iharkút (western Hungary) (Fig. 1) has yielded a rich vertebrate fauna (Ösi et al. 2012) since its discovery in 2000. Squamates are relatively well represented in this assemblage and thus Iharkút is among the few European Upper Cretaceous localities which provide remains suitable for comparison with material from North America or Asia. In the Iharkút material, anguimorphs are the most abundant regarding the number of remains since the first known freshwater mosasaur Pannoniasaurus inexpectatus Makádi, Caldwell and Ösi, 2012 (Makádi et al. 2012) is known from hundreds of cranial and postcranial remains. However, Scincomorpha is dominant in the squamate fauna in terms of diversity. The most frequently recovered lizard is the polyglyphanodontine borioteiioid Bicuspidon aff. hatzegiensis Folie and Codrea, 2005 represented by several lower jaws (including complete dentaries and partial mandibles) (Makádi 2006), as well as by unpublished new material. Another polyglyphanodontine, Distortodon rhomboideus Makádi, 2013, and the chamopsiid Pelsochamops infrequens Makádi, 2013 have been described recently (Makádi 2013a,b). All these genera could be assigned to a higher (e.g. family) level taxon because they exhibited the diagnostic characters of their particular clade. Terrestrial lizards described from the locality so far were shown to belong to groups common in North American localities. 
A right mandible with robust dentition, found at the Iharkút locality, proved to be a scincomorph different from these previously identified Iharkút lizards. Investigations proved that it also differs from any other known squamate at generic level. However, referral to a higher taxon is problematic and an extensive comparison with various taxa was made in order to clarify its possible affinities, as well as to determine its possible diet.

Institutional abbreviations.—MTM, Magyar Természettudományi Múzeum (Hungarian Natural History Museum), Budapest, Hungary; MNHN Muséum National d'Histoire Naturelle, Paris, France.

\section{Geographical and geological setting}

The Iharkút locality is situated in the Bakony Mts, Western Hungary near the villages Németbánya and Bakonyjákó (Fig. 1A). Here, the flood plain and channel deposits of the Csehbánya Formation are exposed within an open-pit bauxite mine. The Csehbánya Formation is a flood plain and channel deposit built up of variegated clay, siltstone with grey and brown sand, sand and sandstone beds (Haas et al. 1977; Mindszenty et al. 1984; Knauer and Siegl Farkas 1992; Jocha-Edelényi 1996; Ösi and Mindszenty 2009) that overlies both the Nagytárkány Bauxite Formation and the Triassic Main Dolomite Formation (Fig. 1B).

The most important vertebrate site within the mine is the bonebed of the SZ-6 site (Fig. 1C) and has yielded also the subject of this study. This is an approximately $2-3 \mathrm{~m}$ thick sequence of beds, similar to other cyclic sequences of the Csehbánya Formation at the locality. The bonebed at the base of the sequence is $10-50 \mathrm{~cm}$ thick and overlies a green clay that has a thickness of several meters. This fossiliferous basal breccia is further composed of gray sand, siltstone, clay clasts, pebbles, and plant debris (including charcoal). Intermittent layers of finer sediments indicate periodic deposition in lower energy circumstances (Fig. 
1C). The fossils are predominately fragmentary bones, but occasional well-preserved bones are recovered. This basal breccia was previously interpreted as a result of a crevasse splay (Ösi et al. 2012), but now is thought to be a density flow deposited in a later abandoned channel (Botfalvai et al. 2014). The majority of the vertebrate remains have been found in this sediment by either picking out by hand or screenwashing the sediment left behind after looking for larger bones.

A Santonian age was suggested for the Csehbánya Formation (Knauer and Siegl Farkas 1992). This age was confirmed and narrowed down more specifically to the fossiliferous beds recently by paleomagnetic and palynological data from samples acquired at the SZ-6 site (Szalai 2005; Bodor and Baranyi 2012).

\section{Material and methods}

The present paper describes a partial right mandible (MTM V2010.129.1.) (Figs. 2, 3). The specimen is housed in the Hungarian Natural History Museum (MTM) in the vertebrate paleontological collections.

MTM V2010.129.1. was found in the bonebed of the SZ-6 site (Fig. 1C) similarly to most of the Iharkút vertebrate material. Screenwashing at Iharkút, though useful for searching for microvertebrate fossils, usually destroys relatively larger microvertebrate remains because the bones are full of cracks and are sometimes held together only by the matrix. Thus the mandible was found by checking through the bonebed and picking out by hand.

The specimen was glued with cyanoacrylic and fixed with PVB (polyvinyl-butyral). Most Iharkút vertebrates are blackish-brownish of pyrite and organic material (Tuba et al. 2006), but MTM V2010.129.1. shows a large variety of colors from black to whitish yellow due to the oxidation of pyrite. This made the imaging of the specimen rather difficult, since 
ammonium-chloride coating could not have been applied because the grains of the coating hide fine details.

Following the practice of previous studies (Nydam and Cifelli 2002; Makádi 2013b), in the description of the dentition, tooth positions were numbered (e.g., first, second, third, etc.), beginning with the most anterior tooth position. When referring to a particular tooth, it is done based on its position, e.g. 'the tooth at the first tooth position'.

For the anatomical descriptions of the dentition the orientation terminology proposed by Smith and Dodson (2003) was used. In this terminology, 'mesial' (and 'distal') indicate tooth surfaces and directions facing toward (and away from) the mandibular symphysis (or the median sagittal plane of the animal). 'Labial' (and 'lingual') stand for those surfaces and directions which face the lips or cheeks (and those which face the tongue). 'Basal' is used for the direction toward tooth bases, 'apical' is for the direction toward crown tips, 'occlusal' is used for views of the occlusal surfaces.

For the demonstration of crushing dentition in recent squamates in Figure 4, photographs of the specimens of the Collection of Reptiles and Amphibians of the Muséum National d'Histoire Naturelle, Paris have been used. The images were made by one of the authors (LM) in 2009 and are used with the kind permission of Salvador Bailon.

\section{Systematic paleontology}

Order: Squamata Oppel, 1811

Infraorder: Scincomorpha Camp, 1923

Family: Familia incertae sedis

Genus: Chromatogenys gen. nov.

Derivatio nominis: Meaning "colored jaw", from the Greek words "khroma" meaning color, and "genys", jaw, indicating the colorful nature of the holotype. 
Type species: Chromatogenys tiliquoides sp. nov., monotypic; see below.

Diagnosis: as for the species; see below

Chromatogenys tiliquoides sp. nov. (Figs. 2-3).

Synonymy: 2012. Scincomorpha indet. B, Ösi et al., p. 549.

Derivatio nominis: "Tiliqua-like", referring to the similar dentition and possible diet as the recent skink Tiliqua.

Holotype: MTM V2010.129.1. partial right mandible preserving dentary and crushed postdentary bones (surangular).

Type locality and horizon: Iharkút open-pit bauxite mine, Bakony Hills, western Hungary, Upper Cretaceous (Santonian) Csehbánya Formation (Ösi et al. 2012).

Diagnosis: Scincomorphan lizard with a unique combination of characters: dentary robust and ventrally strongly convex; large medially inclined subcircular symphysis; anteriorly abruptly thickening subdental shelf in medial view; subdental shelf posterior process interdigitating with anteromedial process of coronoid; intramandibular septum extending posteriorly well beyond level of last tooth position; elongate insertion area for coronoid on large coronoid process of dentary; reduced tooth count; deep sulcus dentalis; pleurodont teeth with mesiodistally compressed tooth shafts and labiolingually compressed, lingually striated, squared-off crowns; minute blunt ridges flanking crowns mesially and distally; large and bulbous posterior teeth. Differs from chamopsiids in the lack of barrel-shaped teeth with crowns with a conical apex and bordering mesial and distal accessory ridges; lack of cementum deposition at base of teeth. Differs from polyglyphanodontines in lack of subpleurodonty with heavy cementum deposition at tooth bases; different tooth morphology lacking transversally widened or complex crowns. Differs from xantusiids in lack of closed and fused Meckelian canal and fused spleniodentary. Differs from contogeniids in having more robust, curved dentary; lacking shelf-like lateral expansion on posterior part of dentary; 
lack of triangular arrangement of first three mental foramina on dentary; intramandibular septum extending posteriorly well beyond last tooth position; lack of mesiodistally directed apical grooves on tooth crowns.

Remarks: The term 'Scincomorpha' is used sensu Estes et al. (1988) throughout this study. See explanation in 'Possible phylogeny' section.

\section{Description}

The mandible is $20 \mathrm{~mm}$ long and it is composed of the dentary and some crushed postdentary bones, most probably the surangular (Fig. 2). No suture lines are visible on the specimen, and the crushed surangular cannot be examined due to the damage of the posterior portion of the specimen.

The dentary is robust and ventrally strongly convex in medial view but it is straight in dorsal view. The lateral surface of the dentary bears a row of seven mental foramina, the first of these (at the level of the fourth tooth position) is ,misaligned” ventrally from the row. The lateral surface shows no signs of ornamentation.

The symphysis is unusually large, subcircular and inclined slightly medially. It is angled to the longitudinal axis of the jaw at approximately $30^{\circ}$ in dorsal view. Its surface is limited to the dorsal edge of the Meckelian canal. It is more developed than in contogeniids, chamopsiids or polyglyphanodontines except Polyglyphanodon sternbergi Gilmore, 1940 (Gilmore 1942a; Nydam et al. 2007; Nydam and Fitzpatrick 2009; Nydam et al. 2010).

The Meckelian canal is open as in most scincomorphs, in contrast to xantusiids or Catactegenys solaster Nydam, Rowe and Cifelli 2013 (Nydam and Fitzpatrick 2009; Nydam et al. 2013). The ventral edge of the Meckelian canal is bent and displaced dorsally as a result of a longitudinal breakage. However, its original form can be reconstructed easily indicating 
that the posteriorly wide canal was abruptly narrowing anteriorly approximately at the level of the ninth tooth place (about the midpoint of the tooth-bearing portion of the bone). Anteriorly it is open as a narrow slit extending under the symphysis in a slightly ventral position. The form of the canal suggests that the splenial was relatively short, as in e.g. scincids or some cordylids (Estes et al. 1988; Kosma 2004: figs. 6,9,18-19).

The intramandibular septum extends posteriorly well beyond the last tooth position and is fused to the floor of the Meckelian canal as in contogeniids, however, the degree of this extension is greater in Chromatogenys, terminating posteriorly beyond the level of the last tooth at a distance approximately equal to the width of the last empty tooth place. The posterior margin of the intramandibular septum lacks the small pointed process described for Utahgenys evansi Nydam and Fitzpatrick, 2009. In contrast to contogeniids, a lateral expansion of the inferior alveolar canal is not present, thus no shelf is visible on the lateral margin of the posterior dentary (Estes 1969a; Nydam and Fitzpatrick 2009).

The sulcus dentalis is deep and narrow. The subdental shelf is well developed and thickens abruptly in anterior direction at the point below the $10^{\text {th }}$ tooth position in medial view, similarly to Estescincosaurus cooki (Estes, 1964) or paramacellodids (Estes 1964, 1983, Sullivan and Lucas 1997). Its dorsal border is mostly straight except its anterior and posterior ends. Anteriorly it rises abruptly to partially support the symphysis, while posteriorly right after the last tooth position it rises to form a pointed process which most probably interdigitated with the anteromedial process of the coronoid. In dorsal view it is visible that this process was most probably accepted by a V-shaped recess on the anterior edge of the articulation facet of the coronoid.

Similarly to both contogeniids and xantusiids such as Palaeoxantusia (Hecht 1956; Gao and Fox 1996; Nydam and Fitzpatrick 2009), the dentary has a well-developed coronoid articulation facet on the medial surface of the coronoid process of the dentary but it is more 
elongate than in contogeniids in medial view. The anterior process of the coronoid lacks the more vertical orientation described for Contogenys ekalakaensis Nydam and Fitzpatrick, 2009 in medial view. The coronoid facet on the dentary, similarly to Palaeoscincosaurus and in contrast to Contogenys ekalakaensis, does not extend anteriorly until the level of the most posterior tooth position. The overlap between these two bones also seems to be larger than in Contogenys (Nydam and Fitzpatrick 2009). The dentary covered the anterior process of the coronoid in lateral view as in scincids, cordylids or contogeniids (Estes et al 1988; Nydam and Fitzpatrick 2009). The coronoid process of the dentary is tall and curves medially to overlap the anterior process of the coronoid, partially hiding it also from dorsal view.

As a result of the state of preservation, it is not known whether the surangular process was longer than the coronoid process (hypertrophied surangular process) as in Contogenys or xantusiids or more or less equal, as in scincids (Estes et al. 1988; Gao and Fox 1996; Nydam and Fitzpatrick 2009).

The last preserved tooth exhibits a moderate sized circular foramen at its base, which can be interpreted as a resorption pit. The preceding preserved tooth, however, has a small foramen at its base, similar to those described as nutrient foramina in Utahgenys evansi (Nydam and Fitzpatrick 2009: 687, fig. 7H).

The dentary bears 12 tooth places with nine teeth, the eighth, $10^{\text {th }}$ and $12^{\text {th }}$ (last) tooth positions are empty. However, the crowns are preserved only on the teeth of the first, seventh, ninth and $11^{\text {th }}$ positions, and these crowns exhibit some abrasion damage on their tips. The teeth are pleurodont as in most lizards and show only a minimal amount of cementum deposition between the teeth, unlike the subpleurodont condition seen in teiids or borioteiioids (Estes et al. 1988; Nydam et al. 2007). They project one third (or less in the case of the last, most posterior tooth) of their height above the lateral parapet of the dentary and have similar height and increasing diameter in posterior direction. 
The dentition is more or less heterodont and resembles the dentition of certain species of the recent skink genus Tiliqua, especially Tiliqua gigas (Schneider, 1801) (Kosma 2004). The anteriormost tooth, having its crown preserved, is tiny, pointed and peg-like, similarly to Palaeoscincosaurus middletoni Sullivan and Lucas, 1996 and has a large subcircular resorption pit at its base (Sullivan and Lucas 1996) (Fig. 2A,B). The more posterior broken teeth have mesiodistally compressed cross-sections similar to Tiliqua scincoides (White, 1890) (Kosma 2004) (Fig. 2B). The shape of the main body of the teeth resembles the 'mushroom-shaped' anterior tooth shafts of young specimens of Tiliqua gigas. This appearance is due to the mesiodistally compressed shafts and labiolingually compressed crowns. The crowns of teeth preserved at the seventh, ninth and $11^{\text {th }}$ positions (Fig. 2,3) are slightly compressed labiolingually. The tooth crowns are also squared-off ('truncated') as in contogeniids (Nydam and Fitzpatrick 2009). The crown of the tooth at the seventh position is concave lingually as in paramacellodids (Estes 1983; Evans and Chure 1998) or in Tiliqua scincoides (Kosma 2004). As opposed to the more elongated shafts of the tooth at the seventh position, the most posterior preserved tooth at the $11^{\text {th }}$ tooth place is large and bulbous, similarly to Tiliqua gigas or Hemisphaeriodon gerrardi (Gray, 1845) (Kosma 2004), while the tooth at the ninth position shows an intermediate form. A minor apical wear is present on the crowns of the teeth at the ninth and $11^{\text {th }}$ tooth places. In the case of the preceding preserved tooth (seventh position) this wear is not so obvious as a result of the state of preservation.

Faint, mesiodistally directed apical depressions are visible on the tips (Fig. 3B), similarly to Tiliqua scincoides (Kosma 2004). These structures are hardly visible shallow and narrow excavations on the mesial and distal edges of the crowns of the ninth and $11^{\text {th }}$ teeth in occlusal view. Similar to the well-developed apical grooves of Palaeoscincosaurus, these excavations terminate in the minute blunt ridges which flank the crowns mesially and distally (Sullivan 
and Lucas 1996; Nydam and Fitzpatrick, 2009). These ridges are weakly developed and extend basally to wrap around the crown lingually, not unlike in chamopsiids such as Pelsochamops (Makádi 2013b). The crowns lack the tricuspid appearance of Socognathus (Nydam et al. 2010: 1094, fig. 4D) or the true tricuspid teeth of Utahgenys in labial view (Nydam and Fitzpatrick 2009).

The tooth crowns bear strong, radially arranged apical striae on their lingual sides similarly to Tiliqua (Kosma 2004), but the labial surfaces of the teeth are too heavily worn or damaged to determine if striae were present (Fig. 3C). The lingual striae are pronounced on the teeth at the ninth and $11^{\text {th }}$ positions which have less crown damage, but they are only faintly visible on the tooth at the seventh position (Fig. 3A,B). It is not known whether the tooth crowns had a distinct striation also on their labial sides as recent skinks with similar dentition (Kosma 2004).

The last, $12^{\text {th }}$ tooth place, though empty, indicates a tooth having even larger dimensions as the preceding one, suggesting a large and possibly bulbous posteriormost tooth.

\section{Discussion and conclusions}

Chromatogenys is regarded as a scincomorph on the basis of the open Meckelian canal, the wide subdental shelf with deep sulcus dentalis, and the pleurodont teeth. However its assignment at familiar level within Scincomorpha is more problematic. Difficulties with referral of clearly distinct genera to more inclusive clades are expected because jaws and dentaries in particular, are limited in the available diagnostic information. In order to justify its distinction as a new genus, a thorough comparison is necessary with members of the different groups within Scincomorpha, and also, at first, with taxa which were not assigned to 
any of these subclades due to uncertainty. Regardless of the higher taxonomic status of such finds, we have been able to compare most of them to MTM V2010.129.1. as follows.

\section{Cretaceous scincomorphans from Europe}

First, it was necessary to investigate the possible relationships of MTM V2010.129.1. to European taxa from the Cretaceous. Several squamates are known from the Lower Cretaceous of Europe, however these are mostly assigned as basal scleroglossans, or basal scincomorphs and differ markedly from Late Cretaceous forms like Chromatogenys (e.g. Evans 1994, 2003; Evans and Barbadillo 1996, 1997, 1998a,b; Evans et al. 2004, 2006; Bolet and Evans 2010, 2011; Houssaye et al. 2013a; Rage 2013).

Terrestrial lizard remains from the Late Cretaceous of Europe are known from various localities in France (Buffetaut et al. 1996; Buffetaut et al. 1997; Gheerbrant et al. 1997; Buffetaut et al. 1999; Tabuce et al. 2004; Buffetaut 2005; Vullo and Néraudeau 2008; Vullo et al. 2011), Spain (Rage 1999; López-Martínez et al. 2000; Company 2004; Blain et al. 2010; Narváez and Ortega 2010; Houssaye et al. 2013b), and Romania (Grigorescu et al. 1999; Codrea et al. 2002; Venczel and Csiki 2003; Folie and Codrea 2005; Grigorescu 2005; Csiki et al. 2008; Codrea et al. 2010a,b; Grigorescu 2010; Vasile and Csiki 2010; Weishampel et al. 2010; Vasile and Csiki 2011; Codrea et al. 2012; Jipa 2012). However, most of these are not sufficiently known to compare with Chromatogenys, or well-known North American or Asian taxa. Material from Europe is scarce, those specimens which were described and figured are either not scincomorphs, or have a morphology radically different from MTM V2010.129.1. (Gheerbrant et al. 1997; Rage 1999; Codrea et al. 2002; Csiki et al. 2008; Vullo and Néraudeau 2008; Blain et al. 2010; Narváez and Ortega 2010; Vullo et al. 2011; Codrea et al. 2012, Rage 2013). 
There were only a few exceptions when these scincomorphs could be determined at genus or species level (Folie and Codrea 2005; Folie et al. 2005; Makádi 2006, 2013a,b). Material adequate for comparisons is available mainly at Iharkút and in Transylvania. Indeed, previously described Iharkút squamates, with the exception of the freshwater mosasaur Pannoniasaurus, are scincomorphs. The polyglyphanodontines Bicuspidon aff. hatzegiensis and Distortodon rhomboideus, and the chamopsiid Pelsochamops infrequens, all belong to groups described from North America, and differ from Chromatogenys (see below) (Makádi 2006, 2013a,b; Makádi et al. 2012). Scincomorphs from the Maastrichtian of Transylvania are again Bicuspidon hatzegiensis, as well as the paramacellodids Becklesius nopcsai Folie and Codrea, 2005 and Becklesius cf. B. hoffstetteri Estes, 1983 (Folie and Codrea 2005).

However, paramacellodids have typical tooth morphology different from that of Chromatogenys (see below).

Asian or North American taxa are more numerous and/or better preserved and thus there is more material suitable for comparison. Nevertheless, sometimes even complete jaws or skulls are limited in the available diagnostic information and other materials to compare with, and are described with no doubt as new genera or species but cannot be assigned to any clade within Scincomorpha with sufficient certainty.

Cretaceous scincomorphans with ambiguous relationships

Scincomorphs described from Asia with unknown or dubious familiar relationships are mainly from the Upper Cretaceous of the Gobi Desert. Slavoia darevskii Sulimski, 1984, a scincomorph with unknown familiar relationships from the Campanian of the Khulsan and Khermeen Tsav localities, has an even more robust mandible than Chromatogenys but weakly developed symphysis, and a reduced splenial with the Meckelian groove being widely open 
anteriorly. Like Chromatogenys, it has a reduced tooth count with widely spaced teeth, but those are slightly anteriorly inclined, high, cylindrical and peg-like with pointed apices and without striae (Sulimski 1984; Gao and Norell 2000).

Globaura venusta Borsuk-Białynicka, 1988 and Eoxanta lacertifrons Borsuk-Białynicka, 1988 are known from various Campanian localities of the Gobi and were assigned to Lacertoidea by Borsuk-Białynicka (1988). Gao and Norell (2000), however, considered them as Scincomorpha incertae sedis. Both have more developed splenials, and smaller symphysis than Chromatogenys, moreover, Globaura has a Meckelian canal turning to the ventral side dentary anterior to the splenial and has a smaller overlap of the dentary on the coronoid in lateral view. It also has straight columnar teeth with a tiny additional cusp mesial to the main cusp on the crowns. Eoxanta also has columnar teeth but with transversely widened crowns (Borsuk-Białynicka 1988; Gao and Norell 2000).

Gao and Norell (2000) also described another scincomorph from Ukhaa Tolgod as "New genus and species (unnamed)", and referred it as Familia incertae sedis. This species has a straight mandible in lateral view as opposed to Chromatogenys, and its splenial covers the posterior two thirds of the Meckelian canal with the anterior canal being only narrowly open. The teeth on the dentary were not described since they were not exposed for observation but its maxillary teeth were very tiny (Gao and Norell 2000).

Several Upper Cretaceous scincomorphs were described also from North America without certain familiar relationships. Ptilotodon wilsoni Nydam and Cifelli, 2002 from the Aptian-Albian of Oklahoma, was originally described as a teiid, based on the cementum deposition on the tooth bases, large subcircular resorption pits and transverse widening of the tooth crown, unlike Chromatogenys. Later it has been reassigned as Scincomorpha indet. (Nydam 2013). Its tooth crowns bear well-developed mesial and distal expansions different from those of MTM V2010.129.1. Nydam (2013) also described new taxa such as 
Dakotasaurus gillettorum Nydam, 2013, Webbsaurus lofgreni Nydam, 2013, and

Monocnemodon syphakos Nydam, 2013, as well as various indeterminate scincomorphans.

These all exhibit dental and mandibular morphology different from that of Chromatogenys.

Bothriagenys mysterion Nydam, 2002, a possible scincomorph, was described from the Albian-Cenomanian of Utah. Unlike Chromatogenys, it has a straight dentary in medial view with a Meckelian canal being moderately wide only at the very posterior end of the bone, remaining open only as a narrow slit for most of its length anteriorly. Its teeth are also different, being tall, narrow, and conical (Nydam 2002).

Apsgnathus triptodon Nydam, Rowe and Cifelli, 2013 from the Campanian of Texas, has a subdental shelf thickening in posterior direction as opposed to Chromatogenys. Moreover, it exhibits a narrow Meckelian canal, heavy cementum deposition at the tooth bases, and the anterior process of its coronoid extends to the level of the most posterior tooth, in contrast to MTM V2010.129.1. (Nydam et al. 2013).

Kleskunsaurus grandeprairiensis Nydam, Caldwell and Fanti, 2010 was described from the Campanian of Alberta, and has a straight dentary with columnar widely spaced narrow teeth, again unlike Chromatogenys (Nydam et al. 2010).

Prototeius stageri Denton and O’Neil, 1995 was originally described as a chamopsiine teiid, but later was regarded as a species with uncertain affinities. Though it has crushing molariform teeth posteriorly, also has an enlarged caniniform third dentary tooth, in contrast to MTM V2010.129.1. The presence of an intramandibular septum is also dubious on its dentary, it has a shallow sulcus dentalis, and an elongated symphysis (Denton and O'Neil 1995; Nydam et al. 2010).

Longrich et al. (2012) recently described several new taxa from the Maastrichtian of Western North America. Obamadon gracilis Longrich, Bhullar and Gauthier, 2012, the „Laramie Chamopsiid” and the „Frenchman Chamopsiid” have mixed chamopsiid or 
polyglyphanodontine characters, e.g. elongated mandibular symphysis, tricuspid tooth crowns or mesial and distal ridges wrapping around a blunt central cusp. Obamadon was considered a 'Polyglyphanodontia' incertae sedis, while the „Laramie Chamopsiid” and the „Frenchman Chamopsiid" were assigned to Chamopsiidae, both groups not related to Chromatogenys (see below). Lonchisaurus trichurus Longrich, Bhullar and Gauthier, 2012 was assigned as Scincomorpha incertae sedis. In contrast to Chromatogenys, it has an elongate dentary and weakly posteriorly curved, columnar, closely packed teeth with crowns bearing blunt-pointed apices. However, they are similar in having well-developed subcircular symphysis, deep Meckelian canal expanded posteriorly but constricted anteriorly, as well as an anteriorly thick subdental shelf tapering posteriorly in medial view, though in Lonchisaurus it is extremely slender posteriorly and the tapering is gradual as opposed to Chromatogenys (Longrich et al. 2012).

\section{Lacertids/teiids}

When compared with the individual subclades of Scincomorpha, Chromatogenys seems to be similar to scincids, cordylids, borioteiioids, contogeniids and xantusiids in that its dentary covers the anterior coronoid process in lateral view, a character shared by these taxa, as opposed to lacertids or teiids whose dentition is also unlike that of MTM V2010.129.1. (Estes 1983; Krause et al. 2003; Kosma 2004; Nydam et al. 2007; Nydam and Fitzpatrick 2009). On the other hand, Pachygenys thlastesa Gao and Cheng, 1999, a lacertoid, was described from the Lower Cretaceous of China as having its anterior coronoid process covered by the lateral dentary, moreover, it also seems to have surangular and coronoid processes of about the same length similar to scincids (Estes et al. 1988; Gao and Cheng 1999: fig. 3-4). Similarly to Chromatogenys, it has a robust, ventrally convex dentary in lateral view, anteriorly thick 
subdental shelf supporting the symphysis and narrowing abruptly in posterior direction, Meckelian canal similarly being a narrow groove anterior to splenial, a long anterior process of coronoid on dentary in medial view, and a reduced tooth count. In contrast, the splenial of Pachygenys extends more anteriorly, its closely packed teeth are situated anteriorly on the dentary far from the coronoid insertion area, its teeth are procumbent anteriorly, vertical in the middle, and posteriorly inclined in the back of the tooth row (Gao and Cheng 1999). It is difficult to suggest a relationship between the two genera because both seem to be specialized. Chromatogenys is very different from lacertids or teiids, thus it is reasonable to investigate its possible relationship with other scincomorphan groups.

\section{Borioteiioids}

The robust dentary and the heterodont dentition of Chromatogenys resemble borioteiioids. However, MTM V2010.129.1. does not exhibit characters typical for the clade, e.g. subpleurodonty with heavy cementum deposition at the tooth bases, or a hypertrophied splenial (Nydam et al. 2007).

Comparing with taxa within Borioteiioidea, Chromatogenys neither has the typical transversally widened teeth of polyglyphanodontines such as Polyglyphanodon, Paraglyphanodon, Dicothodon, Bicuspidon, or Distortodon (Gilmore 1940, 1942a, 1943;

Estes 1983; Nydam 1999; Nydam and Cifelli 2002, 2005; Folie and Codrea 2005; Nydam et al. 2007; Makádi 2006, 2013b; Nydam 2013). It also lacks complex crown morphology like that of Peneteius (Estes 1969b; Nydam et al. 2000).

Asian borioteiioids also have radically different dentary and tooth morphology with polycuspate, leaf-like (Gilmoreteius [=Macrocephalosaurus], Darchansaurus, Erdenetosaurus, Kuwajimalla) and obliquely widened polycuspate (Cherminsaurus) teeth, 
only Adamisaurus having bulbous tooth crowns but a subacrodont tooth attachment (Sulimski 1972, 1975; Estes 1983; Alifanov 2000, Evans and Manabe 2008).

Chromatogenys does not have the synapomorphies of Chamopsiidae, such as relatively widely spaced barrel-shaped teeth, conical or tricuspid tooth crowns, long mandibular symphysis and absence of a bony intramandibular septum, and differs from each member of the group. Crowns with bordering mesial and distal accessory ridges are found in both some chamopsiids and Chromatogenys, possibly due to a plesiomorphic basic crown morphology, being present in many scincomorphan groups (Estes 1964, 1983; Gao and Fox 1996; Nydam and Voci 2007; Nydam et al. 2010; Makádi 2013b).

\section{Xantusiids/contogeniids}

Xantusiids like the Eocene Palaeoxantusia, as well as Paracontogenys, now regarded as another Eocene xantusiid, are well distinguishable from Chromatogenys by a closed and fused Meckelian canal and the fusion of the splenial and the dentary (Hecht 1956; Schatzinger 1980, Estes 1983; Gao and Fox 1996; Nydam et al. 2013). Unlike Chromatogenys, the possible Cretaceous xantusiid Catactegenys has a shallow sulcus dentalis and teeth which do not extend to the sulcus dentalis. Its posterior teeth have cementum deposition around their bases, while their crowns have somewhat different morphology with well-developed antrum intercristatum anterior and posterior (Nydam et al. 2013).

Similarly to polyglyphanodontines and chamopsiids, the presence of contogeniids would not be surprising in the Iharkút fauna. However, the shelf-like lateral expansion on the posterior part of the dentary of contogeniids is not present in Chromatogenys. Neither is the double row of mental foramina on the anterior dentary, the triangular arrangement of the first three foramina is lacking (Nydam and Fitzpatrick 2009; Nydam et al. 2013). The length of the 
surangular process (thus the presence of a hypertrophied surangular process, characteristic for contogeniids) (Nydam and Fitzpatrick 2009) cannot be determined on MTM V2010.129.1. due to state of preservation. Nevertheless, it can be deduced if the surangular process had been longer than the coronoid process, then the tooth-bearing portion of the dentary would have had only slightly more than half the total length of the dentary. This seems to be highly unlikely in case of a durophagous dentition and diet that needs a mandible with a short lever arm and high torque. The condition of this character might have been more similar to that of scincids (Estes et al. 1988) having surangular and coronoid processes of about the same length, or the surangular process might have been even shorter than the coronoid process as figured for some lacertids (Estes et al. 1988: fig. 22).

The anteroposteriorly directed apical grooves of contogeniids are also different from the similar depressions visible on MTM V2010.129.1. These shallow and narrow occlusal excavations on the mesial and distal edges of the crowns of Chromatogenys are reminiscent of the similar structures described for Tiliqua, or can be interpreted as wear facets common to bulbous teeth (Sullivan and Lucas 1996; Kosma 2004; Nydam and Fitzpatrick 2009). Currently we cannot accept these as being diagnostic, but their presence along with other dental features provides help in determining the diet of the animal.

The truncated (squared-off) tooth crown morphology is a feature found in contogeniids (Nydam and Fitzpatrick 2009), but is also present in the slightly more pointed teeth of the possible scincid Aocnodromeus and has arisen independently in anguids (e.g. Odaxosaurus piger (Gilmore, 1928), Odaxosaurus priscus Gao and Fox, 1996, Proxestops jepseni (Gilmore, 1942)) (Gilmore 1928, 1942b; Estes 1964; Gao and Fox 1996). The lingual inclination of the originally probably higher seventh tooth crown resembles e.g. Eumeces or paramacellodids (Estes 1983; Evans and Chure 1998; Kosma 2004). The distinct articulation facet for the coronoid on the medial surface of the dentary suggests a more elongate 
articulation with the coronoid than in contogeniids. The anterior process of the coronoid also lacks the steep, more vertical orientation found in e.g. Contogenys (Estes et al. 1988; Gao and Fox 1996; Nydam and Fitzpatrick 2009). The well-developed, posteriorly extending intramandibular septum is common in Contogeniidae, but the degree of this extension in Chromatogenys, terminating more posteriorly, does not fall within the range described for that clade and might be unique. Chromatogenys also differs from the individual members of Contogeniidae. For example, in the case of Contogenys, the anterior process of the coronoid extends anteriorly so far that it almost reaches the level of the last, most posterior tooth position, but this contact area is relatively small. The uniformly thickening subdental shelf of Contogenys is also different from the abruptly thickening shelf of Chromatogenys. The long articulation between the coronoid and dentary on MTM V2010.129.1. differs from the dorsoventrally more extended facet in Palaeoscincosaurus. The latter also has smaller teeth at the back of the tooth row while Chromatogenys has posterior teeth having the same height (and greater width) as the ones in the middle of the tooth row. Utahgenys has distinct tricuspid tooth crowns and a small pointed process on the posterior margin of the intramandibular septum, not present in Chromatogenys (Sullivan and Lucas 1996; Nydam and Fitzpatrick 2009; Nydam 2013).

On the other hand, the posterior teeth of Chromatogenys resemble those of Palaeoscincosaurus pharkidodon Nydam and Fitzpatrick, 2009. When trying to compensate the wear/damage on the teeth of MTM V2010.129.1. in order to reconstruct the original crowns, it is likely that the $11^{\text {th }}$ tooth was somewhat similar to the one figured for $P$. pharkidodon (e.g. robust teeth with labiolingually compressed tooth crown, weakly developed mesial and distal crests running medially and basally, apical striae) (Nydam and Fitzpatrick 2009: fig.6D). Similarly, the anterior teeth of Chromatogenys were probably similar to the more anterior teeth of $P$. pharkidodon (Nydam and Fitzpatrick 2009: fig. 6E). However, as 
mentioned before, this kind of tooth morphology of Chromatogenys is also reminiscent of Tiliqua, thus these similarities may be due to similarity in feeding strategy rather than relatedness. The tooth crown morphology of Chromatogenys resembles some scincids at least as much as some contogeniids and is most probably more dependent on similar ecology rather than similar phylogenetic position. Contogeniidae was diagnosed by a unique combination of characters, and Chromatogenys does not fulfill the criteria necessary to be referred to the clade (Nydam and Fitzpatrick 2009). Those contogeniid features which are present in Chromatogenys are dubious and insufficient not even for placing it in the group, but also to indicate a closer relationship than to e.g. scincids.

\section{Paramacellodids/cordylids}

Paramacellodids and cordylids are traditionally thought to be closely related to scincids and were grouped together in Scincoidea by some authors (Estes et al. 1988; Gauthier et al. 2012) though a recent study placed cordylids closer to lacertids and paramacellodids to anguimorphs (Conrad 2008). Atokasaurus metarsiodon Nydam and Cifelli, 2002 is a possible paramacellodid from the Aptian-Albian Antlers Formation. It has swollen tooth bases with sigmoidal outline with a cusp being inclined lingually on the lingually concave tooth crown, bordered by mesial and distal carinae. Moreover, its teeth attach to the bone well above the sulcus dentalis (Nydam and Cifelli 2002b). Well-known paramacellodids like Paramacellodus, Becklesius or Saurillodon also have medially swollen tooth bases, columnar teeth, and lingually concave and inclined tooth crowns with triangular lingual and labial cusps. These characters are also shared by cordylids (Estes 1983; Evans and Searle 2002; Kosma 2004), but represent a tooth morphology unlike that of MTM V2010.129.1. They also seem to have an anteriorly much further extending splenial, a weaker symphysis, and higher 
tooth count than Chromatogenys, though they share the anteriorly thick subdental shelf that thins posteriorly in medial view (Estes 1983: figs. 28-29). This character together with a short splenial ending anteriorly at the level of the middle of the tooth row, seems to occur also in recent cordylids (Kosma 2004: figs. 6,9,18-19). Konkasaurus mahalana Krause, Evans and Gao, 2003 is a possible cordylid from the Maastrichtian of Madagascar. It has a straighter dentary in lateral view and a more medially inclined symphysis dorsal view than Chromatogenys, though they both have the anteriorly thickening subdental shelf mentioned above. The dentition of Konkasaurus is heterodont with small, heavily worn teeth anteriorly and larger bicuspid or slightly tricuspid teeth posteriorly (Krause et al. 2003). Gao and Fox (1996) also mentioned possible cordylids from Canada as 'genus and species undetermined (A)' and consecutively '(B)'. Both have a shallow or weakly developed sulcus dentalis and a small symphysis as opposed to Chromatogenys, but similarly they exhibit the anteriorly thick, posteriorly narrowing subdental shelf in medial view. However, 'genus and species undetermined (A)' has unicuspid tooth crowns the tip which of curves lingually and is bordered by mesial and distal carinae and lacks striae. 'B' has faintly developed accessory cusps (Gao and Fox 1996).

\section{Scincoids}

Nevertheless, other characters, for instance, the abrupt anterior narrowing of the posteriorly wide Meckelian canal with a relatively short splenial, are common in scincids (Estes et al. 1988). Estescincosaurus cooki (Estes, 1964), a possible scincoid from the Maastrichtian of Wyoming, has a strong symphysis similarly to Chromatogenys. Moreover, it also has an anteriorly broad subdental shelf that thins posteriorly in medial view, an anteriorly narrow Meckelian canal that is open until the symphysis as a narrow groove, though this part of the 
canal has more ventral position than in the latter. The intramandibular septum of Estescincosaurus fuses to the floor of the Meckelian canal below the 17th (of 26) tooth position (RLN personal observation), which is well anterior of the position in Chromatogenys. Its slightly heterodont dentition consists of a much higher number of closely spaced, subcylindrical teeth with slightly compressed crowns which are also slightly inclined distally. The crowns exhibit lingual apical striae and multiple cusps. The anterior teeth have a single main cusp with or without a reduced mesial cusp, in the middle of the tooth row the smaller cusp becomes more prominent, while further posteriorly the crowns are tricuspid (Estes 1964; Sullivan 1997; Longrich et al. 2012).

Parmeosaurus scutatus Gao and Norell, 2000 was described from the Campanian of Mongolia as a possible scincoid and has a massive, but straight dentary in lateral view, a welldeveloped splenial extending far anteriorly in contrast to Chromatogenys. Its dentary also bears relatively slender and unicuspid teeth anteriorly, teeth with stout and bicuspid crowns with a small anterior accessory cuspule on the middle part of the tooth row while the most posterior teeth are short-crowned, very stout, and weakly tricuspid (Gao and Norell 2000). Hymenosaurus clarki Gao and Norell, 2000 was found at the same Ukhaa Tolgod locality as Parmeosaurus, and similarly, it was referred to as a possible scincoid. Unlike Chromatogenys, it has a very slender mandible, has a narrow subdental shelf, and a long splenial almost reaching to the symphysis. Its closely packed teeth are slender and cylindrical. Due to preservation, the morphology of the crowns is unknown (Gao and Norell 2000).

Scincoideus haininensis Folie, Sigé and Smith, 2005 was described as a possible scincoid from the Paleocene of Belgium, but regarded by some authors (J. Müller pers. comm.) as the synonym of Eolacerta from the Eocene of same geographic area (Müller 2002). Otherwise, it has posteriorly widely open Meckelian canal gradually narrowing anteriorly, a smaller symphysis, greater tooth count, tooth crowns bearing well-developed triangular shaped 
lingual and labial cusps, no striae on crowns and a mesial crest longer than the distal crest encompassing the crown. Conclusively, both its dentary and tooth morphology differs from that of Chromatogenys (Folie et al. 2005).

Gao and Fox (1996) described three new genera as scincids from the Upper Cretaceous of Alberta, Penemabuya, Orthrioscincus and Aocnodromeus. Penemabuya has a much slender dentary with a narrow subdental shelf in medial view, a poorly developed sulcus dentalis and a narrow Meckelian canal. Its teeth are long, slender and curved posteriorly. Orthrioscincus also has a more gracile dentary, weak sulcus dentalis and narrow subdental shelf as well as strongly bicuspid teeth. Aocnodromeus, similarly to Chromatogenys, has a more robust dentary, thick subdental shelf narrowing in posterior direction, its posterior teeth are more robust, squared-off and compressed labiolingually. However, it has a narrow Meckelian canal, its teeth have crowns which are medially concave with a single cusp positioned distally to the midpoint of the tooth. Moreover, all these three genera seem to have a weakly developed symphysis.

Possible phylogeny

MTM V2010.129.1. shows traits which are common in Scincomorpha sensu Estes et al. (1988). However, recently Scincomorpha has come under intense scrutiny as a clade as a result of both morphology-based and molecular-based analyses (Townsend et al. 2004; Vidal and Hedges 2009; Wiens et al. 2010; Gauthier et al. 2012; Pyron et al. 2013), though some authors still found it monophyletic (Conrad 2008). Whether Scincomorpha sensu Estes et al. (1988) is a valid clade or not, the subject of this study is not higher level taxonomy, thus MTM V2010.129.1. is regarded as a belonging to Scincomorpha of Estes et al. (1988). However, in the phylogeny of e.g. Pyron et al. (2013) it would possibly be a member of 
Scincoidea, even though herein it is not formally assigned to Scincoidea sensu Estes et al. (1988) due to the lack of diagnostic characters. A phylogenetic analysis is far beyond the goals of this study, and in our opinion the lack of material makes an analysis of

Chromatogenys unreasonable. However, the morphology of MTM V2010.129.1. clearly shows that it is different from any previously described genus. It exhibits a mixture of characters of different clades, such as scincids, cordylids or contogeniids. Through the careful comparisons above, we are able to demonstrate the diagnostic nature of MTM V2010.129.1., even though we cannot confidently refer it to a higher taxon and only may tentatively refer it to Scincoidea. To indicate this uncertainty, Chromatogenys is formally assigned here only as Scincomorpha Familia incertae sedis.

The insular nature of the European localities with the nearly complete lack of comparative material in the region, and the apparent isolation of the Western Interior of North America (the Laramidia island continent), as well as the isolation of Asian faunas can result in the expectation of numerous groups of lizards heretofore unknown to science. To determine whether Chromatogenys is the first recognized representative of an undescribed clade, or belongs to a previously known group, requires additional material, both locally and globally.

Diet

The plain and smooth labial surfaces of the tooth crowns of Chromatogenys resemble wear facets (Fig. 3C), and thus would suggest similar wear on the occluding lingual side of the maxillary teeth, ever to be found. This type of shearing tooth contact between maxillary and dentary teeth, more suitable for cutting, however, contradicts the apical wear on the apices, thus it is more reasonable to regard these 'facets' on MTM V2010.129.1. as a result of taphonomic processes unless more material is found with similar features. 
In contrast, the large, interdigitating articulation surface between the coronoid and the well-developed coronoid process of the dentary suggests a massive coronoid for adductor muscle attachment. Together with the strong symphysis, robust posterior teeth and the apical wear on the tooth crowns, they indicate a durophagous lifestyle for Chromatogenys tiliquoides, moreover, the resemblance to the dentition of Tiliqua gigas and T. scincoides (Fig. 4A) indicates similar diet. This includes snails, eggs, insects, small vertebrates, as well as fruits. The teiid Tupinambis teguixin has more pyramidal and tricuspid posterior tooth crowns (Fig. 4B) but has almost the same diet consisting of plant matter, earthworms, snails, arthropods, small vertebrates and eggs. These examples are in contrast to the more specialized Hemispheriodon which has even more robust crushing teeth than Tiliqua (or Chromatogenys) and consumes almost exclusively mollusks. (Kosma 2004). The bonebed at the type locality, besides vertebrate fossils, also yielded remains of invertebrates such as gastropods. The seeds from the plant genus Sabia and various Normapolles-related plants have been also described from the fossiliferous layers of the locality (Bodor 2011; Bodor and Baranyi 2012; Bodor et al. 2012). Thus the different potential food sources were available for Chromatogenys in the same paleoenvironment.

Durophagous diet is common in different groups of recent and fossil lizards (Estes and Williams 1984) thus it is not unexpected to find one also in the Santonian of the western Tethyan Archipelago. Chromatogenys might have been an ecological counterpart of recent skinks which can feed on 'hard' prey like insects and molluscs, as well as fruits and seeds. Modern clades such as true lacertids, scincids or cordylids do not appear unequivocally in the Mesozoic, not especially in Europe (Evans 2003; Rage 2013). Extinct groups of scincomorphs in the European Late Cretaceous, such as chamopsiids and polyglyphanodontines, as well as genera with uncertain taxonomy like Chromatogenys could have been substitutes for modern groups which emerged later in the Paleogene. 
If more specimens of Chromatogenys are ever to be found, they could help to clarify its taxonomic position, while future investigations (e.g. microwear analysis, preferably on a larger number of specimens) can refine our knowledge of the feeding behavior of these animals.

\section{Acknowledgements}

The authors wish to thank A. Ösi and the other members of the Iharkút Research Group, the staffs of the Geological and Geophysical Collections, Geological and Geophysical Institute of Hungary, of the Dept. of Paleontology, Eötvös University and of the Dept. of Geology and Paleontology, Hungarian Natural History Museum for their help provided. Reviewers Jack L. Conrad and Johannes Müller are gratefully acknowledged for critically reading the manuscript and making useful suggestions that greatly improved our work. The authors are grateful to Salvador Bailon from the Muséum National d'Histoire Naturelle for the access to recent comparative material. The help of Christoph Wißing and Márton Rabi with the German version of the abstract is highly appreciated. The fieldwork and the work of LM was supported by the Hungarian Scientific Research Fund (OTKA) NF-84193, as well as the Hungarian Academy of Sciences (MTA) "Lendület" Grant (MTA-ELTE Dinosaur Research Group, grant n.: 95102) grants. Previously, research at Iharkút was supported by the OTKA T-39045 and PD-73021 grants; the National Geographic Society; the Jurassic Foundation; the Hungarian Oil and Gas Company Plc (MOL Nyrt) and the Hantken Foundation. Fieldwork was also supported by the Bakonyi Bauxitbánya Ltd, the Geovol Ltd and the Céltrans 97 Ltd, as well as many others.

\section{References}


Alifanov, V.R. 2000. Macrocephalosaurs and the early evolution of lizards of Central Asia. Moscow: GEOS [in Russian].

Blain, H.-A., J.-I. Canudo, G. Cuenca-Bescós, and N. López-Martínez. 2010. Amphibians and squamate reptiles from the latest Maastrichtian (Upper Cretaceous) of Blasi 2 (Huesca, Spain). Cretaceous Research 31(4): 433-446.

Bodor, E.R. 2011. Plant mesofossils of the Upper Cretaceous Iharkút vertebrate fossil site (Bakony Mts., Hungary). The 8th Romanian Symposium of Paleontology Abstract Book: $4-5$.

Bodor, E.R., and V. Baranyi. 2012. Palynomorphs of the Normapolles group and related plant mesofossils from the Iharkút vertebrate site, Bakony Mountains (Hungary). Central European Geology 55(3): 259-292.

Bodor, E.R., V. Baranyi, and Z. Heřmanová. 2012. The earliest Sabiaceae fruit remains of Hungary. Hantkeniana 7(Monostori Jubilee Volume): 11-18.

Bolet, A., and S.E. Evans. 2010. A new lizard from the Early Cretaceous of Catalonia (Spain), and the Mesozoic lizards of the Iberian Peninsula. Cretaceous Research 31(4): 447-457.

Bolet, A., and S.E. Evans. 2011. New material of the enigmatic Scandensia, an Early Cretaceous lizard from the Iberian Peninsula. Special Papers in Palaeontology 86: 99 108.

Borsuk-Białynicka, M. 1988. Globaura venusta gen. et sp. n. and Eoxanta lacertifrons gen. et sp. n. - non-teiid lacertoids from the Late Cretaceous of Mongolia. Acta Palaeontologica Polonica 33(3): 211-248.

Botfalvai, G., A. Ősi, and A. Mindszenty. 2014. Taphonomic and paleoecologic investigations of the Late Cretaceous (Santonian) Iharkút vertebrate assemblage (Bakony Mts, Northwestern Hungary). Palaeogeography, Palaeoclimatology, Palaeoecology (available online), doi: 10.1016/j.palaeo.2014.09.032 
Buffetaut, E. 2005. Late Cretaceous Vertebrates from the Saint-Chinian area (Southern France): a review of previous research and an update on recent finds. Acta Palaeontologica Romaniae 5: 39-48.

Buffetaut, E., G. Costa, J. Le Loeuff, M. Martin, J.-C. Rage, X. Valentin, and H. Tong. 1996. An Early Campanian vertebrate fauna from the Villeveyrac Basin (Hérault, southern France). Neues Jahrbuch für Geologie und Paläontologie Monatshefte 1996: 1-16.

Buffetaut, E., J. Le Loeuff, H. Tong, S. Duffaud, L. Cavin, G. Garcia, and D. Ward. 1999. Un nouveau gisement de vertébrés du Crétacé supérieur à Cruzy (Hérault, Sud de la France). Comptes Rendus de l'Académie des Sciences, Sciences de la Terre 328(3): 203-208.

Buffetaut, E., J. Le Loeuff, L. Cavin, S. Duffaud, E. Gheerbrant, Y. Laurent, M. Martin, J.-C. Rage, H. Tong, and D. Vasse. 1997. Late Cretaceous non-marine vertebrates from southern France: a review of recent finds. Geobios 20: 101-108.

Camp, C. 1923. Classification of the lizards. Bulletin American Museum of Natural History 48: $289-481$.

Codrea, V., O. Barbu, and C. Jipa-Murzea. 2010a. Upper Cretaceous (Maastrichtian) land vertebrate diversity in Alba District (Romania). Bulletin of the Geological Society of Greece 43(2): 594-601.

Codrea, V., M. Venczel, and A.I. Solomon. 2012. Squamate diversity of the Late Cretaceous 'Haţeg Island', Romania - Gondwanan links. Geologica Belgica 16(4): 154.

Codrea, V., T. Smith, P. Dica, A. Folie, G. Garcia, P. Godefroit, and J. van Itterbeeck. 2002. Dinosaur egg nests, mammals, and other vertebrates from a new Maastrichtian site of the Haţeg Basin (Romania). Comptes Rendus Palevol 1(3): 173-180.

Codrea, V., M. Vremir, C. Jipa, P. Godefroit, Z. Csiki, T. Smith, and C. Fărcaş. 2010b. More than just Nopcsa's Transylvanian dinosaurs: A look outside the Haţeg Basin. Palaeogeography, Palaeoclimatology, Palaeoecology 293(3-4): 391-405. 
Company, J.R. 2004. Vertebrados continentales del Cretácico Superior (CampanienseMaastrichtiense) de Valencia. $\mathrm{PhD}$ thesis, Valencia: Universitat de València. [in Spanish] Conrad, J.L. 2008. Phylogeny And Systematics Of Squamata (Reptilia) Based On Morphology. Bulletin of the American Museum of Natural History 310: 1-182.

Csiki, Z., Ionescu, A., and Grigorescu, D. 2008. The Budurone microvertebrate site from the Maastrichtian of the Haţeg Basin - flora, fauna, taphonomy and paleoenvironment. Acta Palaeontologica Romaniae 6: 49-66.

Denton, R.K., and R.C. O’Neil. 1995. Prototeius stageri, gen. et sp. nov., a new teiid lizard from the Upper Cretaceous Marshalltown Formation of New Jersey, with a preliminary phylogenetic revision of the Teiidae. Journal of Vertebrate Paleontology 15(2): 235-253.

Estes, R. 1964. Fossil vertebrates from the Late Cretaceous Lance Formation, eastern Wyoming. University of California Publications in Geological Sciences 49: 1-186.

Estes, R. 1969a. A scincoid lizard from the Cretaceous and Paleocene of Montana. Breviora 331: 1-9.

Estes, R. 1969b. Relationships of two Cretaceous lizards (Sauria, Teiidae). Breviora 317: 1-8. Estes, R. 1983. Encyclopedia of Paleoherpetology Series, Part 10a: Sauria terrestria, Amphisbaenia. Stuttgart and New York: Gustav Fischer Verlag.

Estes, R., and E. E. Williams. 1984. Ontogenetic variation in the molariform teeth of lizards. Journal of Vertebrate Paleontology 4(1): 96-107.

Estes, R., K. de Queiroz, and J. Gauthier. 1988. Phylogenetic relationships within Squamata. In Phylogenetic relationships of the lizard families - Essays commemorating Charles L. Camp, eds. Estes, R., and G. Pregill, 119-281. Stanford University Press, Stanford. Evans, S.E. 1994. A new anguimorph lizard from the Jurassic and Lower Cretaceous of England. Palaeontology 37(1): 33-49. 
Evans, S.E. 2003. At the feet of the dinosaurs: the early history and radiation of lizards. Biological Reviews of the Cambridge Philosophical Society 78(4): 513-551.

Evans, S.E., and L.J. Barbadillo. 1996. The Early Cretaceous lizards of Montsec (Catalonia, Spain). Treballs del Museu de Geologia de Barcelona 5: 5-13.

Evans, S.E., and L.J. Barbadillo. 1997. Early Cretaceous lizards from Las Hoyas, Spain. Zoological Journal of the Linnean Society 119(1): 23-49.

Evans, S.E., and L.J. Barbadillo. 1998a. An unusual lizard (Reptilia: Squamata) from the Early Cretaceous of Las Hoyas, Spain. Zoological Journal of the Linnean Society 124(3): $235-265$.

Evans, S.E., and L.J. Barbadillo. 1998b. The lizard Rubiessaurus Gómez Pallerola, 1979 from the Lower Cretaceous of Catalonia (Montsec, Lleida, Spain). Treballs del Museu de Geología de Barcelona 7: 5-10.

Evans, S.E., and D.J. Chure. 1998. Paramacellodid lizard skulls from the Jurassic Morrison Formation at Dinosaur National Monument, Utah. Journal of Vertebrate Paleontology 18(1): 99-114.

Evans, S.E., and M. Manabe. 2008. An early herbivorous lizard from the Lower Cretaceous of Japan. Palaeontology 51(2): 487-498.

Evans, S.E., and B. Searle. 2002. Lepidosaurian reptiles from the Purbeck Limestone Group of Dorset, southern England. In Life and environment in Purbeck Times, eds. Milner, A.R., and D.J. Batten, 145-159. London: Palaeontological Association.

Evans, S.E., P. Raia, and C. Barbera. 2004. New lizards and rhynchocephalians from the Lower Cretaceous of southern Italy. Acta Palaeontologica Polonica 49(3): 393-408.

Evans, S.E., P. Raia, and C. Barbera. 2006. The lower Cretaceous lizard genus Chometokadmon from Italy. Cretaceous Research 27(5): 673-683. 
Folie, A., and V. Codrea. 2005. New lissamphibians and squamates from the Maastrichtian of Haţeg Basin, Romania. Acta Palaeontologica Polonica 50(1): 57-71.

Folie, A., B. Sigé, and T. Smith. 2005. A new scincomorph lizard from the Palaeocene of Belgium and the origin of Scincoidea in Europe. Naturwissenschaften 92(11): 542-546.

Gao, K., and Z. Cheng. 1999. A New Lizard from the Lower Cretaceous of Shandong, China. Journal of Vertebrate Paleontology 19(3): 456-465.

Gao, K., and R.C. Fox. 1996. Taxonomy and evolution of Late Cretaceous lizards (Reptilia: Squamata) from western Canada. Bulletin of the Carnegie Museum of Natural History 33: $1-107$.

Gao, K., and M.A. Norell. 2000. Taxonomic Composition and Systematics of Late Cretaceous Lizard Assemblages from Ukhaa Tolgod and Adjacent Localities, Mongolian Gobi Desert. Bulletin of the American Museum of Natural History 249: 1-118.

Gauthier, J.A., M. Kearney, J.A. Maisano, O. Rieppel, and A.D.B. Behlke. 2012. Assembling the Squamate Tree of Life: Perspectives from the Phenotype and the Fossil Record. Bulletin of the Peabody Museum of Natural History 53(1): 3-308.

Gheerbrant, E., C. Abrial, and H. Capetta. 1997. Nouveaux sites a microvertébrés continentaux du Crétacé terminal des Petites Pyrénées (Haute-Garonne et Ariège, France). Geobios 20: 257-269.

Gilmore, C.W. 1928. Fossil lizards of North America. Memoirs of the National Academy of Sciences 22: 1-201.

Gilmore, C.W. 1940. New fossil lizards from the Upper Cretaceous of Utah. Smithsonian Miscellaneous Collections 99(16): 1-3.

Gilmore, C.W. 1942a. Osteology of Polyglyphanodon, an Upper Cretaceous Lizard from Utah. Proceedings of the United States National Museum 92: 229-265. 
Gilmore, C.W. 1942b. Paleocene Faunas of the Polecat Bench Formation, Park County, Wyoming, Part II. Lizards. Proceedings of the American Philosophical Society 85(2): $159-167$.

Gilmore, C.W. 1943. Osteology of Upper Cretaceous Lizards from Utah, with a description of a new species. Proceedings of the United States National Museum 93: 209-214.

Gray, J.E. 1845. Catalogue of the specimens of lizards in the collection of the British Museum. 289 pp. London.

Grigorescu, D. 2005. Rediscovery of a 'forgotten land': the last three decades of research on the dinosaur-bearing deposits from the Haţeg Basin. Acta Palaeontologica Romaniae 5: $191-204$.

Grigorescu, D. 2010. The Latest Cretaceous fauna with dinosaurs and mammals from the Haţeg Basin - A historical overview. Palaeogeography, Palaeoclimatology, Palaeoecology 293(3-4): 271-282.

Grigorescu, D., M. Venczel, Z. Csiki, and R. Limberea. 1999. New latest Cretaceous microvertebrate fossil assemblages from the Haţeg Basin (Romania). Netherlands Journal of Geosciences 78(3-4): 301-314.

Haas, J., E. Jocha-Edelényi, and G. Császár. 1977. Study of Mesozoic formations of the Transdanubian Central Mountains in Hungary. Annual Report of the Geological Institute of Hungary of the year 1975: 259-272. [in Hungarian]

Hecht, M.K. 1956. A new xantusiid lizard from the Eocene of Wyoming. American Museum Novitates 1774: 1-8.

Houssaye, A., N. Bardet, I. Narváez, and F. Ortega. 2013a. Squamate finding in "'Lo Hueco" (Late Campanian-Early Maastrichtian, Cuenca Province, Spain): the second non-marine pythonomorph lizard. Paläontologische Zeitschrift 87(3): 415-422. 
Houssaye, A., J.-C. Rage, F.T. Fernández-Baldor, P.H. Hurtado, N. Bardet, and X.-P. Suberbiola. 2013b. A new varanoid squamate from the Early Cretaceous of Burgos, Spain. Cretaceous Research 41: 127-135.

Jipa, C.-C. 2012. Upper Cretaceous continental vertebrate assemblages from Metaliferi sedimentary area: sytematics, paleoecology and paleobiogeography. $\mathrm{PhD}$ thesis English abstract, Cluj-Napoca: Babeş-Bolyai University.

Jocha-Edelényi, E. 1996. Csehbánya Formation, Ajka Coal Formation. In Basic Lithostratigraphic Units of Hungary, ed. G. Császár, 61-66. Budapest: Geological Institute of Hungary. [in Hungarian]

Knauer, J., and Á. Siegl Farkas. 1992. Palynostratigraphic position of the Senonian beds overlying the Upper Cretaceous bauxite formations of the Bakony Mts. Annual Report of the Geological Institute of Hungary of the year 1990: 463-471. [in Hungarian]

Kosma, R. 2004. The dentitions of recent and fossil scincomorphan lizards (Lacertilia, Squamata) - Systematics, Functional Morphology, Paleoecology. PhD thesis, Hannover: Universität Hannover.

Krause, D.W., S.E. Evans, and K. Gao. 2003. First Definitive Record of Mesozoic Lizards from Madagascar. Journal of Vertebrate Paleontology 23(4): 842-856.

Longrich, N.R., B.-A.S. Bhullar, and J.A. Gauthier. 2012. Mass extinction of lizards and snakes at the Cretaceous-Paleogene boundary. PNAS 109(52): 21396-21401.

López-Martínez, N., J.I. Canudo, L. Ardèvol, X.-P. Suberbiola, X. Orue-Etxebarria, G. Cuenca-Bescós, J.I. Ruiz-Omeñaca, X. Murelaga, and M. Feist. 2000. New dinosaur sites correlated with Upper Maastrichtian pelagic deposits in the Spanish Pyrenees: implications for the dinosaur extinction pattern in Europe. Cretaceous Research 22(1): $41-61$. 
Makádi, L. 2006. Bicuspidon aff. hatzegiensis (Squamata: Scincomorpha: Teiidae) from the Upper Cretaceous Csehbánya Formation (Hungary, Bakony Mts). Acta Geologica Hungarica 49(4): 373-385.

Makádi, L. 2013a. A new polyglyphanodontine lizard (Squamata: Borioteiioidea) from the Late Cretaceous Iharkút locality (Santonian, Hungary). Cretaceous Research 46: 166176.

Makádi, L. 2013b. The first known chamopsiid lizard (Squamata) from the Upper Cretaceous of Europe (Csehbánya Formation; Hungary, Bakony Mts). Annales de Paléontologie 99(3): 261-274.

Makádi, L., M.W. Caldwell, and A. Ösi. 2012. The First Freshwater Mosasauroid (Upper Cretaceous, Hungary) and a New Clade of Basal Mosasauroids. PLoS ONE 7: e51781. doi:10.1371/journal.pone.0051781

Mindszenty, A., J. Knauer, and F. Szantner. 1984. Sedimentological features and the conditions of accumulation of the Iharkút bauxite. Földtani Közlöny 114(1): 19-48. [in Hungarian]

Müller, J. 2002. Eolacerta from the Eocene of Prémontré, France (Reptilia, Squamata). Neues Jahrbuch für Geologie und Paläontologie, Monatshefte 2002: 490-500.

Narváez, I., and F. Ortega. 2010. Análisis preliminar de los restos de Iguanidae indet. del Cretácico Superior de Lo Hueco (Fuentes, Cuenca). Cidaris 30: 205-209.

Nydam, R.L. 1999: Polyglyphanodontinae (Squamata: Teiidae) from the medial and Late Cretaceous: new taxa from Utah, U.S.A. and Baja California del Norte, Mexico. In Vertebrate Paleontology in Utah, ed. D.D. Gillette, 303-317. Salt Lake City: Utah Geological Survey. 
Nydam, R.L. 2002. Lizards of the Mussentuchit Local Fauna (Albian-Cenomanian boundary) and comments on the evolution of the Cretaceous lizard fauna of North America. Journal of Vertebrate Paleontology 22(3): 645-660.

Nydam, R.L. 2013. Lizards and Snakes from the Cenomanian through Campanian of Southern Utah: Filling the Gap in the Fossil Record of Squamata from the Late Cretaceous of the Western Interior of North America. In At the Top of the Grand Staircase: the Late Cretaceous of southern Utah, eds. A.L. Titus, and M.A. Loewen, 370423. Bloomington: Indiana University Press.

Nydam, R.L., and R.L. Cifelli. 2002a. A new teiid lizard from the Cedar Mountain Formation (Albian-Cenomanian boundary) of Utah. Journal of Vertebrate Paleontology 22(2): 276-285.

Nydam, R.L., and R.L. Cifelli. 2002b. Lizards from the Lower Cretaceous (Aptian-Albian) Antlers and Cloverly Formations. Journal of Vertebrate Paleontology 22(2): 286-298.

Nydam, R.L., and R.L. Cifelli. 2005. New data on the dentition of the scincomorphan lizard Polyglyphanodon sternbergi. Acta Palaeontologica Polonica 50(1): 73-78.

Nydam, R.L. and B.M. Fitzpatrick. 2009. The Occurrence of Contogenys-Like Lizards in the Late Cretaceous and Early Tertiary of the Western Interior of the U.S.A. Journal of Vertebrate Paleontology 29(3): 677-701.

Nydam, R.L., and G.E. Voci. 2007. Teiid-like scincomorphan lizards from the Late Cretaceous (Campanian) of southern Utah. Journal of Herpetology 41(2): 211-219.

Nydam, R.L., M.W. Caldwell, and F. Fanti. 2010. Borioteiioidean lizard skulls from Kleskun Hill (Wapiti Formation; Upper Campanian), West-Central Alberta, Canada. Journal of Vertebrate Paleontology 30(4): 1090-1099. 
Nydam, R.L., J.G. Eaton, and J. Sankey. 2007. New taxa of transversely-toothed lizards (Squamata: Scincomorpha) and new information on the evolutionary history of 'teiids'. Journal of Paleontology 81(3): 538-549.

Nydam, R.L., J. Gauthier, and J.J. Chiment. 2000. The mammal-like teeth of the Late Cretaceous lizard Peneteius aquilonius Estes, 1969 (Squamata, Teiidae). Journal of Vertebrate Paleontology 20(3): 628-631.

Nydam, R.L., T.B. Rowe, and R.L. Cifelli. 2013. Lizards and snakes of the Terlingua Local Fauna (late Campanian), Aguja Formation, Texas, with comments on the distribution of paracontemporaneous squamates throughout the Western Interior of North America. Journal of Vertebrate Paleontology 33(5): 1081-1099.

Oppel, M. 1811. Die Ordnungen, Familien und Gattungen der Reptilien als Prodom einer Naturgeschichte derselben. München: Joseph Lindauer Verlag.

Ösi, A., and A. Mindszenty. 2009. Iharkút, dinosaur-bearing alluvial complex of the Csehbánya Formation. In Cretaceous sediments of the Transdanubian Range, ed. E. Babinszky, 51-63. Budapest, Hungarian Geological Society.

Ősi, A., M. Rabi, L. Makádi, Z. Szentesi, G. Botfalvai, and P. Gulyás. 2012. The Late Cretaceous continental vertebrate fauna from Iharkút (Western Hungary): a review. In Bernissart Dinosaurs and Early Cretaceous Terrestrial Ecosystems, ed. P. Godefroit, 532-569. Bloomington: Indiana University Press.

Pyron, R.A., F.T. Burbrink and J.J. Wiens. 2013. A phylogeny and revised classification of Squamata, including 4161 species of lizards and snakes. BMC Evolutionary Biology 13: $1-53$.

Rage, J.-C. 1999. Squamates (Reptilia) from the Upper Cretaceous of Laño (Basque Country, Spain). Estudios del Museo de Ciencias Naturales de Alava 14: 121-133. 
Rage, J.-C. 2013. Mesozoic and Cenozoic squamates of Europe. Palaeobiodiversity and Palaeoenvironments 93(4): 517-534.

Schatzinger, R.A. 1980. New Species of Palaeoxantusia (Reptilia: Sauria) from the Uintan (Eocene) of San Diego Co., California. Journal of Paleontology 54(2): 460-471.

Schneider, J.G. 1801. Historiae Amphibiorum naturalis et literariae. Fasciculus Secundus continens Crocodilos, Scincos, Chamaesauras, Boas, Pseudoboas, Elapes, Angues, Amphisbaenas et Caecilias. Jena: F. Frommann.

Smith, J.B., and P. Dodson. 2003. A proposal for a standard terminology of anatomical notation and orientation in fossil vertebrate dentitions. Journal of Vertebrate Paleontology 23(1): $1-12$.

Sulimski, A. 1972. Adamisaurus magnidentatus n. gen., n. sp. (Sauria) from the Upper Cretaceous of Mongolia. In Results of the Polish-Mongolian Palaeontological Expeditions, Part IV., ed. Z. Kielan-Jaworowska, Palaeontologia Polonica 27: 33-40.

Sulimski., A. 1975. Macrocephalosauridae and Polyglyphanodontidae (Sauria) from the Late Cretaceous of Mongolia. Palaeontologia Polonica 33: 25-102.

Sulimski, A. 1984. A new Cretaceous scincomorph lizard from Mongolia. Palaeontologia Polonica 46: 143-155.

Sullivan, R.M., and S.G. Lucas. 1996. Palaeoscincosaurus middletoni, new genus and species (Squamata: ?Scincidae) from the early Paleocene (Puercan) Denver Formation, Colorado. Journal of Vertebrate Paleontology 16(4): 666-672.

Sullivan, R.M. 1997. Estescincosaurus cooki (Estes, 1964) new genus (Squamata:

Scincomorpha): replacement name for Sauriscus Lawrence, 1949 (Arachnida:

Trombiculidae). Journal of Vertebrate Paleontology 17(2): 447.

Szalai, E. 2005. Paleomagnetic studies in Iharkút. Manuscript, Budapest: Eötvös University Department of Applied and Environmental Geology. [In Hungarian] 
Tabuce, R., M. Vianey-Liaud, and G. Garcia. 2004. A eutherian mammal in the latest Cretaceous of Vitrolles, southern France. Acta Palaeontologica Polonica 49(3): 347-356.

Townsend, T.M., A. Larson, E. Louis, and J.R. Macey. 2004. Molecular phylogenetics of Squamata: the position of snakes, amphisbaenians, and dibamids, and the root of the squamate tree. Systematic Biology 53(5): 735-757.

Tuba, Gy., P. Kiss, M. Pósfai, and A. Mindszenty. 2006. Preliminary data on the diagenesis of Cretaceous dinosaur bones from the Bakony Mts, Hungary. Földtani Közlöny 136(1): 1-24. [in Hungarian]

Vasile, Ş., and Z. Csiki. 2010. Comparative paleoecological analysis of some microvertebrate fossil assemblages from the Haţeg Basin, Romania. Oltenia. Studii şi comunicări. Ştiinţele Naturii 26(1): 315-322.

Vasile, Ş., and Z. Csiki. 2011. New Maastrichtian microvertebrates from the Ruscă Montana basin (Romania). Oltenia. Studii şi comunicări. Ştiinţele Naturii 27(1): 221-230.

Venczel, M., and Z. Csiki. 2003. New frogs from the latest Cretaceous of Haţeg Basin, Romania. Acta Palaeontologica Polonica 48(4): 609-616.

Vidal, N. and S.B. Hedges. 2009. The molecular evolutionary tree of lizards, snakes, and amphisbaenians. Comptes Rendus Biologies 332(2-3): 129-139.

Vullo, R., and D. Néraudeau. 2008. Cenomanian vertebrate assemblages from southwestern France: a new insight into the European mid-Cretaceous continental fauna. Cretaceous Research 29(5-8): 930-935.

Vullo, R., J.-C. Rage, and D. Néraudeau. 2011. Anuran and squamate remains from the Cenomanian (Late Cretaceous) of Charentes, western France. Journal of Vertebrate Paleontology 31(2): 279-291. 
Weishampel, D.B., Z. Csiki, M.J. Benton, D. Grigorescu, and V. Codrea. 2010.

Palaeobiogeographic relationships of the Haţeg biota - Between isolation and innovation. Palaeogeography, Palaeoclimatology, Palaeoecology 293(3-4): 419-437.

White, J.E. 1790. Journal of a Voyage to New South Wales. London: J. Debrett.

Wiens, J.J., C.A. Kuczynski, T. Townsend, T.W. Reeder, D.G. Mulcahy and J.W. Sites, Jr. 2010. Combining phylogenomics and fossils in higher-level squamate reptile phylogeny: molecular data change the placement of fossil taxa. Systematic Biology 59(6): 675-688.

\section{Figure captions}

Fig. 1 Geography and geological setting of the Iharkút vertebrate locality. Geography (A) and geology (B) of the locality and the most important SZ-6 site $(\mathbf{C})$ within the mine. Q, Quaternary; ICF, Iharkút Conglomerate Formation; CsF, Csehbánya Formation; NBF, Nagytárkány Bauxite Formation; MDF, Main Dolomite Formation

Fig. 2 Holotype partial right mandible (MTM V2010.129.1.) of Chromatogenys tiliquoides gen. nov. sp. nov. from Iharkút. Medial (A), dorsal (B) and lateral (C) views. Numbers indicate the teeth as referred in the text based on their tooth positions

Fig. 3 Closeup of the posterior teeth of the holotype partial right mandible (MTM V2010.129.1.) of Chromatogenys tiliquoides gen. nov. sp. nov. from Iharkút. A. lingual view of the teeth at the seventh, ninth and $11^{\text {th }}$ positions. B. occlusal view of the teeth at the ninth and $11^{\text {th }}$ positions. C. labial view of the tooth at the $11^{\text {th }}$ position. Numbers indicate the teeth as referred in the text based on their tooth positions 
Fig. 4 Examples of durophagous dentitions in recent squamates. A. occlusal-lingual view of the maxillary teeth of the scincid Tiliqua scincoides (MNHN RA 1898-285), anterior is to the left. B. lingual view of dentary teeth of the teiid Tupinambis teguixin (MNHN RA 1891-635), anterior is to the right 